MARKETING AND BRANDING
RESEARCH $\begin{gathered}\text { INDUSTRIAL } \\ \text { MANAGEMENT } \\ \text { INSTITUTE }\end{gathered}$

\title{
Theory and practice of management under threats in tourism
}

\author{
Mariya Stankova, Ivanka Vassenska*
}

${ }^{1}$ Associate Professor, PhD, South-West University “Neofit Rilski” - Blagoevgrad, Faculty of Economics

\begin{abstract}
Keywords:

Threats to Tourism,

Regulations on

Protection, Prevention

Correspondence: ivankav@abv.bg

Threats of natural and social issues and uncertainty are inherent characteristics of the environment in which tourist destinations operate. They are related to specific decisions taken in terms of risk determined for the destination management approaches. Respecting these peculiarities, the study focuses on the problem, which is particularly topical in recent years concerning the events and phenomena threatening the development of tourist destinations. It analyses essential aspects of crisis management, together with the role of the countries and international organizations in this process. The main objective of the study is to explore and analyse the current supranational documents, formulating, controlling, and monitoring the actions against potential and real threats, and it focuses on contemporary theory and practice of regulation and management of threats of natural and social type in Bulgarian tourism. It discusses the tasks which has to be solved and significantly affect the overall process; following this, some promising alternatives to limit the negative effects have been deduced. In the methodological aspect, some theoretical and empirical methods such as analysis, synthesis, induction and deduction, observation, description, and comparison were used.
\end{abstract}

\section{Introduction}

The threats of natural and social origin and the instability are common features of the environment where the tourist destinations function. They are related to specific decisions made in terms of risk, but conditioned for destination management approaches. The analysis and threat assessment suggests actions for their identification, measurement, and mitigation. They are also connected with the fact that the expected effects of their manifestation does not correspond to real benefits or negatives and express different probability for practical 
implementation of the decisions and determinations. The effect of applying one or other approach depends heavily on the views and perceptions about the nature of threats.

Considering the issue of threats to tourist destinations, they certainly cannot be examined separately and independently. This finding comes from the definition of a tourist destination perceived as a geographical entity (Burkart \& Medlik, 1974) or as a private centre, a village or a city (or district) area, island, country or continent, in each case spatially identified. Following this, the geographical indication of a tourist destination provides a convenient focus for the study of potential threats and their diverse impact and importance. In this case it allows linking of international policy on limitation of threats to their dimensions in the various national policies and the specialized documents that are applicable in the different destinations. Also, attention is required for the fact that every distinct threat may cause other resulting effects thereof. For example, the tropical cyclones (known as hurricanes in the Atlantic, cyclones in the Indian Ocean, and typhoons in the Pacific) are accompanied by strong winds, storms, and heavy rainfall leading behind secondary hazards such as floods and landslides. A similar series of threats can trigger a domino effect or the cascade and cause serious distress to the tourist destination such as the nuclear situation in Japan in 2011, the result of an earthquake and tsunami caused by it.

\section{General Review of the Threat Status}

The described specifics are key ones and they determine the direction of the present study in regards of the methodology. They determine the necessity of adopting a complex approach for the analyses and the evaluation of the natural and social threats similar to the methods of the World Bank(Hallegatte \& Przyluski, 2010).

Threats affect individual destinations and countries; so, there is no destination or a country that is not vulnerable to diverse threats. As it is evident from the attached map, areas in East Asia, South and Central America, Iceland and elsewhere are threatened by geophysical threats such as earthquakes and volcanoes; hydro-meteorological threats such as floods, cyclones, and landslides are typical of the eastern coastal regions of the continents, inland areas of North and South America, Europe and Asia while drought is a threat that encompasses more extensive territories worldwide.

On this base, the most threatened are the destinations, respectively the countries located in East and South Asia, as well as the countries of Central and West South America (Figure 1). Many of them are attractive tourist destinations and at the same time are densely populated and economically undeveloped which is a prerequisite for higher potential rate of casualties and damages.

The importance of the individual geographic units as tourist destinations is determined by three factors, namely major attractions, accessibility, and amenities(Burkart \& Medlik, 1974). Before everything else, the attractions of the respective geographical place provoke in people a desire to visit it. Their needs and desires and, generally, their demand generates the supply or the modifications of the destination elements or proposals upon amending this search. This interpretation changes the character of the destination, as well as its structure, but also requires a careful refinement of the approach adopted for reducing threats, threatening it to guarantee a certain acceptable level of resistance to them. 
Figure 1 shows the regions affected by earthquakes with magnitude above 6 on Richter's scale for the period from 1950 to February 2010.

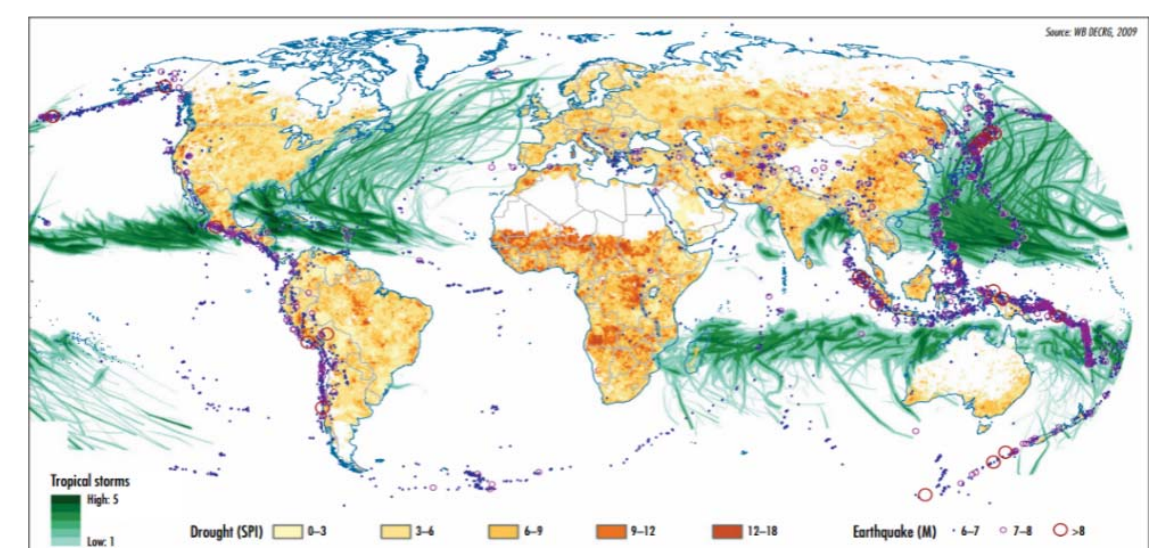

Figure 1. Regions affected by earthquakes with magnitude above 6 on Richter's scale for the period from 1950 to February 2010 (based on data from the Northern California Earthquake Data Centre, www.ncedc.org); tropical storms - for the period 1975 - 2007; draughts (determined on the base of the standardized index of rainfall).

Source: Natural Hazards and Unnatural disasters, The Economics of Effective Prevention, World Bank, 2010. (from http://econpapers.repec.org/bookchap/wbkwbpubs/2512.htm )

In today's increasingly complex socio-economic area, existing threats have global dimensions and are more difficult to overcome. A significant part of them is related to the security of people irrespective of their manifestation in their daily life, leisure, tourism, and travel. Unfortunately, the reality shows that despite the existing possibility of these threats to be identified, they often are not prevented and are not given timely response.

\section{Framework for Stability Provisions against Threats}

Bearing in mind that the issue of limitation and prevention of threats have been always of importance for provision of global stability, it is connected with important interstate agreements in the framework of UN, NATO, and EU. Taken together, they define the main threats that the different countries face and identify the strategies that have to be taken to solve them.

After the collapse of the Soviet Union and the disappearance of the threat of a major war with the Warsaw Pact in 1991, NATO was the first to set new benchmarks and attempts to define threats to the world order when adopted in Rome its first official (and first to became public) concept of the North Atlantic Alliance. Eight years later, in 1999 NATO adopted the Strategic Concept that represents a targeted policy agenda for the future development of the military bloc. It sets the new orientation towards expansion of the scope of responsibility beyond the borders of the member states and redefining the role of the United Nations Security Council on the use of force in one or another part of the world.In Lisbon in 2010, the state and governmental leaders of the member states of NATO adopted Strategic Concept for Defence and Security. This contemporary documentdetermines the course of action of NATO in the so-called "next evolutionary phase of North Atlantic Treaty Organization" in the context of a changing world and new threats.

Following the tendency set up by NATO in 2003 the United States of America also approved their National Security Strategy. The document was published before the beginning 
of the war in Iraq (2003) and is a response reaction of the US to the events of September 11, 2001(Lucas \& McInnis, 2016).In 2015, the White House of the United States of America and the Pentagon passed and adopted a new National Security Strategy of the USA (the White House). Identified as threats are the conflicts and instabilities of the countries, the climatic changes, the access to the "shared spaces" (like cyberspace, space, airspace and oceans), health safety, the distribution and use of weapons for mass destruction (WMD), defined as permanent terrorist threat and the biggest threat to US security.

The place of Europe in the context of the security is led by the Helsinki process which beginning was in 1973, and the adoption of the so-called comprehensive approach to security (comprehensive view of security), underlined in the foundations of the CSCE/OSCE. Security in Europe is seen as integral because the uncertainty of a country or region can affect the wellbeing of all. Twenty years later, in 1995, the first attempt, although considered limited, to define the independent European Security Strategy was made in the framework of the West European Union. The member states accept that in the framework of the General Concept their security is indivisible and the comprehensive approach emphasizes that collective mechanism will be implemented to ensure security and stability throughout the continent. European Security Strategy within the Western European Union is insufficiently known document, although it is the first official European which attempts to assess the evolving security features. Therefore, the Franco-British meeting in Saint-Malo, December 4, 1998 is considered as the starting point in the development of the European Security and Defence Policy (ESDP). The European Security Strategy was adopted five years later, in 2003, which as an official doctrine that describes 5 global and new threats and instabilities in the world, namely international terrorism (especially religious motivation), proliferation of weapons of mass destruction, the problem of so-called failed states, regional conflicts, and organized crime and they are more diverse, less visible, and less predictable (Solana, 2003).

Upon information, provided by Georgieva (2010) - Euro-commissioner for International Cooperation, Humanitarian Aid and Crisis Response(2010-2014) in an interview for Bulgarian National Radio by 2010 the number of disasters has increased 5 times with a tendency for steady growth. According to the Euro-Commissioner, the performed analysis determines four basic reasons for the increase of disasters including climatic changes, demographic factor, increased risk of industrial accidents, and the threat of terrorism. The most affected regions are South-East Asia, Africa, Central America, and the areas around Black and Caspian seas, with population between 100 and 230 million people and damages that amount to nearly 100 billion Euro a year(European Commission, 2015)Annual Report on the European Union's Humanitarian Aid and Civil Protection Policies and their Implementation in 2014).Along with all these, there are time intervals when the cost raises and this is due to exceptional natural conditions. In 2005, the level of costs reaches 180 million Euro after the Katrina hurricane. The highest peak during the period is reached in 2011 as a result of the Honshu tsunami (Figure 2)(European Commission, 2015). The figure depicts clearly the mentioned tendency of increasing natural calamities and if in 1975 the funds spent were 1-2 billion Euros, the funds for 2012 are increased drastically. The summary of the increasing threats is well visible in Figure 2 and 3.

Thus, only in 2014 the European Union spent 1,273million Euros for 121 million people in 80 countries who were affected by natural or man-caused disasters or long-lasting 
crises(European Commission, 2015) in Syria, Iraq, South Sudan, Central African Republic and Ukraine, as well as during the outburst of Ebola virus in Africa. The Civil Protection Mechanism of the EU in 2014 is activated 30 times, mainly because of natural disasters, but also 9 times in man-made disasters (civil strife, conflict, oil pollution, and accidents). Unfortunately, 2015 is shaping up as even more restless and turbulent year and confirms the attitude that whatever the results are, the need for constant improvement of strategic documents and coordination of the use of resources for prevention and response to disasters and crises in the best possible way, should remain the focus of attention.

Figure 2 and 3 display the damages caused by natural calamities in the period 1975-2012and the increasing natural threats, respectively.

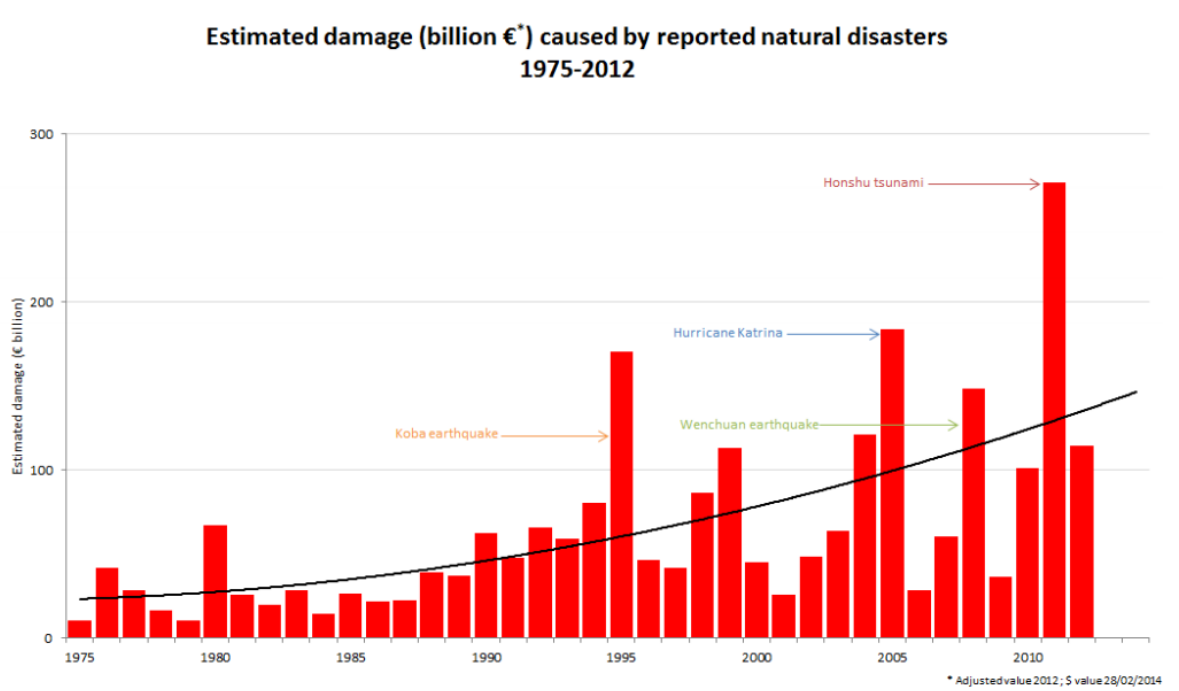

Figure 2. Damages caused by natural calamities in the period 1975-2012

Source: Communication from the Commission to the European Parliament, the European Economic and Social Committee and the Committee of the Regions Framework for Action Hyogo, 2014

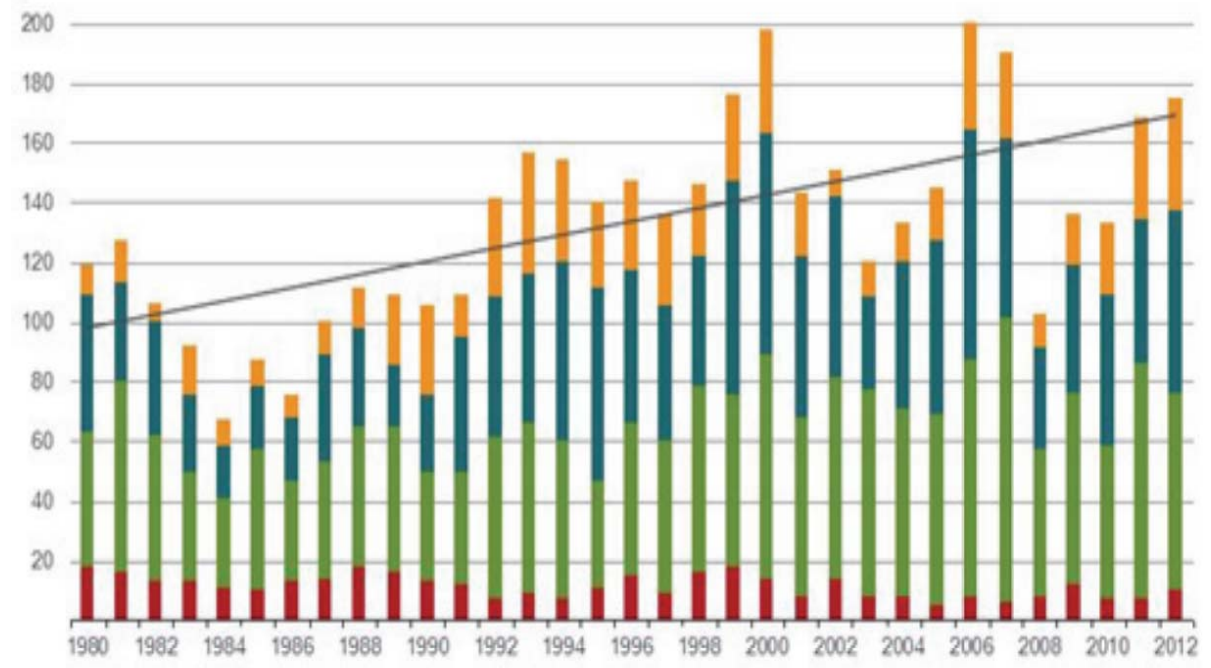

Figure 3. Increasing natural threats 
Source: Communication from the Commission to the European Parliament, the European Economic and Social Committee and the Committee of the Regions Framework for Action Hyogo, 2014

In the EU framework, the reactions to calamities and crises are linked to the national systems for civil protection of each of the member states with the network of collective reaction (functioning through the mechanism of coordination of the civil protection systems of the EU member states and Iceland, Lichtenstein, and Norway) with the Monitoring and Information Centre, with modules for reaction at EU level (with the capacity to solve local as well as trans-border issues) with the Humanitarian Aid Network in the developing countries (European Commission, 2015).

With the increase of the world population and the growth of megacities, pollution, climate change and growing poverty, more and more people face the threats and the effects of disasters and crises. Therefore, a valid system to limit the threats of disasters and crises will be of great benefit to the communities located in vulnerable areas. Better strategies, practices, and response mechanisms such as early warning systems and other activities in the cases of calamities and crises can save lives and speed recovery after extreme weather events, volcanic activities, earthquakes, floods, and war.

The EU has its own program for disaster preparedness ECHO (DIPECHO), launched in 1996. It is an essential element of actions to limit the threats in global perspective and 325 million $€$ (Wilkinson, Robson, \& Sobey, 2014) European Commission and Humanitarian Aid are invested in its development. The main objective of the program is to increase the community resilience and to reduce their vulnerability. DIPECHO is people-oriented program that aims to support the communities exposed to disasters and crises in their preparation and reaction to the threats through training, creation or improvement of the systems of early warning and local plans for emergency situations. It also encourages citizens, informal groups of civil society, and local, regional, and national authorities to work more effectively together. Another key argument are the integrated interventions for diminishing the risks of disasters and crises in carrying out operations in support of affected areas. They are oriented towards the countries where the possibility of risk is high (Figure 4) and where a second occurrence of disaster and crisis is possible so as to reduce the damage by exchanging information and coordinating the supporting actions.

The main objective of ECHO is the assistance in saving and preservation of lives and alleviating human suffering and safeguarding the integrity and human dignity of people affected by natural disasters and man-made crises (Hahn, 2015). Figure 4 exhibits the regions with a high degree of vulnerability as DIPECHO. 


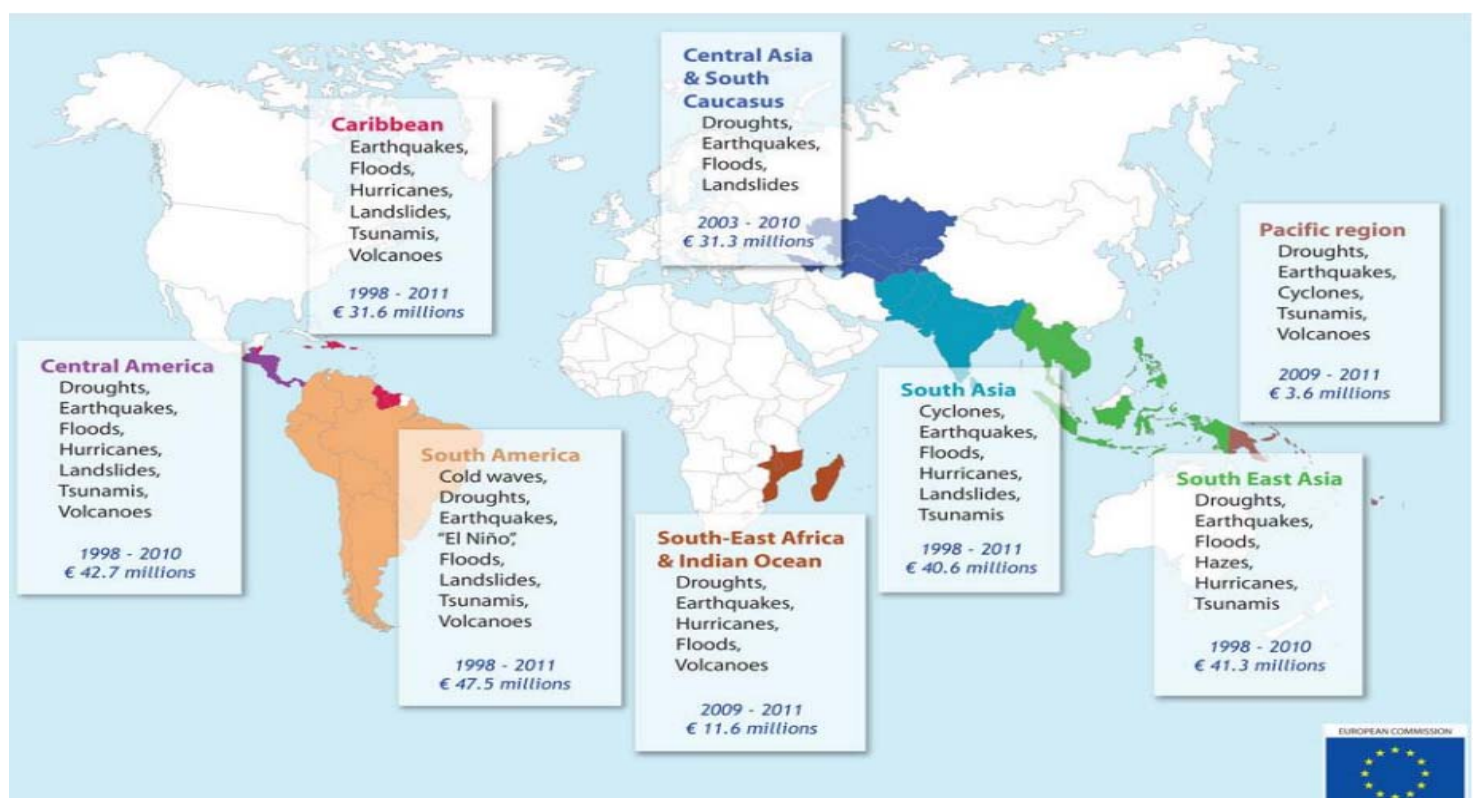

Figure 4. Regions with a high degree of vulnerability as DIPECHO

Source: http://ec.europa.eu/echo/files/evaluation/2014/DRR_Hoa_Cac_Final_Report_EN.PDF

The role of Russia in the balance of international relations in the field of prevention and reduction of natural and social threats is undeniably important. The country has developed a Strategy for National Securityand military doctrine for the period to 2020 based on the principles of analyses of the perspectives for the development of military-political situation and the centralization of the government(McDermott, 2016). It replaces the Concept of National Security of 2000 and is indirectly connected to "Plan a-Putin" and the Concept for Social and Economic Development until 2020.

Some countries have their strategies and security concepts including Bulgaria (2009), Austria (2001), Canada (2001), Australia (2004), Great Britain (2008), Germany (2008), Georgia, Greece (2008), Denmark (concept of common defence of the Cold war), Serbia (2009), France (White Paper on National security and defence), the Netherlands, Croatia, Montenegro, Israel, Jordan, Romania, China, where national security strategies are an extension of foreign policy in economic aspect.

\section{Discussion}

Actually, in national and international aspect strategic frameworks that define the fight with the threats of natural and social origin are available. However, at the same time there are only few examples of available strategies of the tourist destinations related to management of threats. Special attention should be paid to the efforts of the World Tourism Organization and the implemented "Tourism Crisis/ Recovery Committee", providing leadership and guidance to the industry, as well as the activities of World Travel and Tourism Council, National Tour Association, and Travel Security Policy Council.

In fact, a review of documents shows that they lack terminological clarity and clarity in dealing with the concepts of threat, danger, disaster, crisis, and risk. Evidently, as pointed out by Ivanova (2012), the words "threat" and "danger" are synonyms, explained by the possibility and the probability of something bad to happen; "risk" is the possibility of 
something unpleasant, distressed or bad; "disaster" is explained as huge public distress, calamity, catastrophe, and natural disaster; "crisis" occurs in acute deficiency of something or disorder, sudden break, and severe and dangerous situation in the course of something happening. From now on, the focus in this study is a work staging, which agrees with the notion of danger as "bipolar phenomenon poles that are definiteness and indefiniteness". The threats are envisioned as a feature of the environment that precedes the loss of control and the emergency of crisis whereby it may be limited and defined in accordance with the environment and the phenomena that occur in the specifics of this study at the territory of the tourist destination. It is accepted that the threat is "obvious" andthe thread as the risk itself has a different level of intensity and if it grows significantly, it becomes a danger which inevitably precedes the occurrence of an adverse event - "loss of control".

From this position the global trends are clearly distinguishable. Among these,the humanitarian challenges arise from the increasing vulnerability of certain populations and lead to devastating humanitarian disasters such as refugee wave in the autumn of 2015 or the situation in Debaltsevo; endemic internal conflicts loaded with highly ideological content, ranging from asymmetric terrorism to conventional war such as the conflict in Syria; frequent natural disasters - hydro-meteorological phenomena such as landslides and floods (only in 2014 nearly 16000 people were killed and more than 100 million people were affected in 290 natural disasters worldwide of which $34 \%$ are affected by floods and $39 \%$ by draughts (UNISDR).

The map presented in Figure 5 clearly shows the situation in the world at the end of 2014 and the beginning of 2015, illustrating vulnerable areas and areas with concentration of potential threats.

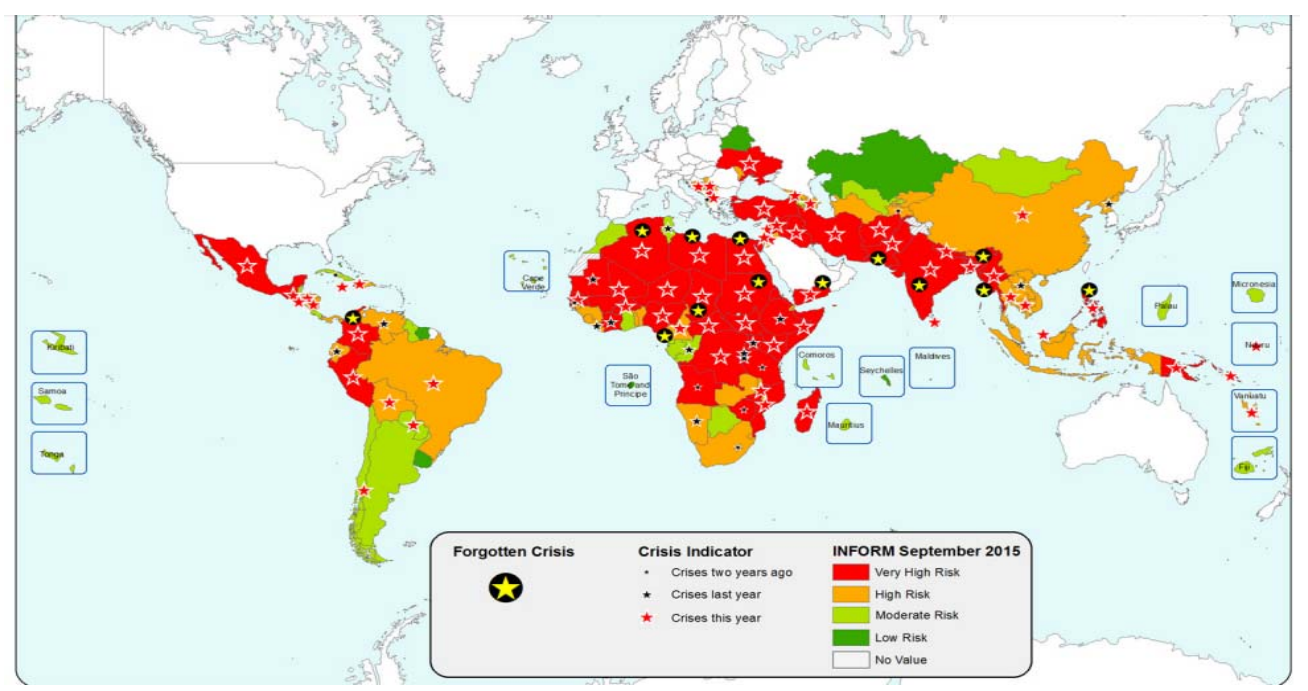

Figure 5. Vulnerability to threats in the world's crisis and "forgotten" crises in 2014

Source: $\underline{\text { http://ec.europa.eu/echo/what/humanitarian-aid/needs-assessments_en }}$

\section{Conclusion}

The world faces a permanent threat of natural cataclysms, namely earthquakes, floods, and landslides (Chile, Guatemala, Nicaragua, the Caribbean, the Caucasus, India, Nepal, 
Afghanistan, Kenya, South Africa, Ethiopia, Serbia, Bosnia and Herzegovina, Kazakhstan); cyclones, hurricanes, tropical storms, and volcano (in the Caribbean, Bangladesh, China, Japan, the Philippines, Indonesia, South Africa, Ecuador); epidemics of Ebola and plague in West Africa, Cameroon, Nigeria, South Sudan, Chad, Democratic Republic of Congo, Ethiopia, Ivory Coast, Niger, Uganda, Afghanistan, Bolivia, Haiti, El Salvador, Honduras, Guatemala, and Nicaragua; drought and fires (in Kenya, Ethiopia, South Africa, Pakistan, Sri Lanka, Chile, Australia, North America); and severe weather (in North America, Armenia). Also, many man-made crises remain as threats: The ongoing fourth year conflict in Syria as the greatest humanitarian crisis and security crisis in the world; instability in Iraq as a humanitarian situation and the situation of poor security; and political instability in the Central African Republic, which provoked unrest and uncertainty amid frequent natural disasters. No less important are internal tensions and armed clashes in South Sudan, where political conflict grew into violence and conflict in eastern Ukraine, as a result of which over 600000 people were displaced and experienced growing humanitarian needs. Under this category falls also the largest outbreak of Ebola virus that began in Africa and spread in the world causing the death of 8000 people in just few months(European Commission, 2015).Attention should be paid to some, known as "forgotten" crises. The concept indicates situations of protracted emergencies to which the international community often do not pay attention such as crisis Sahrawi refugees in Algeria, refugee crisis in the community Rohingya and Chittagong Hill Tracts in Bangladesh, conflict in Jammu and Kashmir, Central India (Naxalite rebellion); Kacin conflict and crisis in rickets in Miyanmar, the population affected by the internal armed conflict in Colombia, and Colombian refugees in Ecuador and Venezuela(European Commission, 2015).

All described threats have their direct and indirect influence over the tourist industry. Phenomena such as Ebola, the syndrome of acute respiratory failure (SARs), tsunamis, hurricanes, earthquakes or volcanic eruptions, wars, crime and terrorism cause shocks to the system of tourism and tourist destinations in the world. Thus, the need for setting strategic response by identifying the most vulnerable locations of the destination and the groups of people to curb the threats and quickly react and provide assistance by coordinating efforts is undeniable(Center for Research on the Epidemiology disaster (CRED) and UN Office for disaster risk reducing (UNISDR), 2015).

\section{References}

Burkart, A. J., \& Medlik, S. (1974). Tourism : past, present and future. London: Heinemann.

Center for research on the epidemiology disaster (CRED) and UN office for disaster risk reducing (UNISDR). (2015). The human cost of weather-related disasters 1995-2015. UN office for disaster risk reducing (UNISDR). Retrieved May 15, 2015, from www.unisdr.org/2015/docs/climatechange/COP21_WeatherDisastersReport_2015_FINAL.pdf

European Commission. (2014). The post 2015 hyogo framework for action: Managing risks to achieve resilience. Brussels: Commission to the European parliament. Retrieved May 25, 2015, from http://ec.europa.eu/echo/files/news/post_hyogo_managing_risks_en.pdf

European Commission. (2015). Annual report on the european union's humanitarian aid and civil protection. Brussels: European commission to the european parliament. retrieved august 27 2016, from http://ec.europa.eu/echo/files/news/post_hyogo_managing_risks_en.pdf

Georgieva, K. (2010, October 22). Кристалина Георгиева: Новата стратегия за реакции при кризи цели възможно найдоброто използване на pecyрса на EC". Bulgarian National Radio. Retrieved August 20, 2016, from http://bnr.bg/radiobulgaria/post/100227863/kristalina-georgieva-novata-strategiya-za-reakcii-pri-krizi-celi-vyzmojno-naidobroto-izpolzvane-na-resursa-na-es 
Hahn, J. (2015, November 24). Commission decisionon on the coordination of the actions of the union and of the member states through a coordination mechanism - the refugee facility for Turkey. Official Journal of the European Union, EURLex, Access to European Union law. Retrieved from http://eur-lex.europa.eu/legalcontent/EN/TXT/?uri=CELEX\%3A32015D1208(02)

Hallegatte, S., \& Przyluski, V. (2010). The economics of natural disasters: Concept and methods (Policy Research Working Paper No. 5507). The World Bank, Washington D.C.

Ivanova, E. (2012). The legal terms "risk" and "threat" in the National Security Strategy of the Republic of Bulgaria. The Scientific Researches by the University of Rousse, 51(7), 250-255.

Lucas, N. J., \& McInnis, K. J. (2016). The 2015 National Security Strategy: Authorities, Changes, Issues for Congress Rep. No. R44023. Congressional Research Service. Retrieved from file://C:/Users/Ivanka/Downloads/nps78-041316$01 \% 20(1) \cdot p d f$

McDermott, R. (2016). Russia's 2015 national security strategy. Eurasia Daily Monitor, 13(7). Retrieved 2016, from jamestown.org/program/russias-2015-national-security-strategy/

Solana, J. (2003). A secure Europe in a better world: European security strategy. Retrieved from EU Institute for Security Studies: /www.iss.europa.eu/uploads/media/solanae.pdf

The World Bank and United Nations. (2010). Natural hazards, unnatural disasters: The economics of effective prevention. Washington D. C.: World Bank Publications. Retrieved May 10, 2015, from http://econpapers.repec.org/bookchap/wbkwbpubs/2512.htm

Wilkinson, C., Robson, L., \& Sobey, M. (2014). Joint evaluation of drought risk reduction in the horn of Africa and DIPECHO central Asia and South Caucasus. The directorate-general humanitarian aid and civil protection. London: ICF Consulting Services Limited. Retrieved May 26,, 2016, from http://ec.europa.eu/echo/files/evaluation/2014/DRR_Hoa_Cac_Final_Report_EN.PDF 